\title{
The First Novel in Xhosa
}

\author{
JEFF OPLAND \\ Godalming, Surrey
}

\begin{abstract}
The first novel in the Xhosa language, USamson, written by the greatest figure in the history of Xhosa literature, S. E. K. Mqhayi (1875-1945), and published in 1907, is now lost. It was produced at a time when black people in South Africa were becoming bolder in their demand for human rights, forming independent black churches and political organizations. It appeared after a period of gestation for Xhosa literature in newspapers, at a time when missionaries were discussing the publication of books in Xhosa, but Mqhayi paid for its printing and organized its distribution. The novelette added details of setting and characterization to the biblical story to encourage the youth to gather behind black leaders who lacked support. Caught in the social tension between Xhosa and Mfengu, USamson was heavily criticized by I. W. Wauchope for departing from biblical narrative, but more generally defended by readers, who looked forward to the further publication of Xhosa literature in books.
\end{abstract}

W

riting and literacy were introduced to the Xhosa-speaking peoples on the Eastern Cape frontier of South Africa by English and Scottish missionaries at the start of the nineteenth century. Printing was initially intended to aid the process of conversion, and early publications in and on the Xhosa language (isiXhosa) were designed to serve the mission community. As literacy and schooling spread, the need was felt for reading material for the converts after they left school, so as from 1837 mission journals and newspapers were established. Ending in 1888, a succession of mission newspapers increasingly attracted Xhosa contributions from native speakers, until an emergent African elite perceived the power of the press and in 1884 began to publish secular newspapers of their own (see Opland, "Fighting with the Pen" and "Nineteenth-Century Xhosa Literature"). These early newspapers fostered a literary cadre from whose ranks were drawn the authors of Xhosa creative writing in books, which appeared in the first decade of the twentieth century. The first novel in Xhosa, entitled USamson (Samson), was published in 1907. Its author, Samuel Edward Krune Mqhayi (1875-1945), was 
throughout his life actively involved in oral tradition as a praise poet (imbongi), for nearly 50 years between 1896 and 1944 he was a prolific contributor to Xhosa newspapers, and is widely acknowledged to be the pre-eminent figure in the history of Xhosa literature.

It is by no means agreed among scholars that Mqhayi's twenty-five-page booklet was the first Xhosa novel, but then again the history of Xhosa literature has not yet been satisfactorily described. Those who write on the subject offer a wide diversity of opinion. Harold Scheub claims that H. M. Ndawo's Uhambo lukaGqoboka (Convert's Journey, 1909) was "the first Xhosa novel" (573). Albert Gérard says that USamson, "an adaptation of the Bible story of Samson," was Mqhayi's first published work but that Ityala lamawele (The Trial of the Twins, 1914) was his "first original work" (54); H. M. Ndawo, however, "should be considered the founder of the Xhosa novel" (63). R. H. W. Shepherd, subsequently editor of the Lovedale Press, which had printed USamson, refers to it as a pamphlet: "A few years afterwards he published a pamphlet entitled Samson. The edition was soon sold out, and people spoke in high terms of it" (Shepherd 113). A. C. Jordan, who himself owned a copy of the book, correctly identified it as "a novelette" (104). Jordan's copy has now gone missing from his collection of papers at the University of Fort Hare, and I have been unsuccessful in my attempts to obtain a copy anywhere, but Wandile Kuse, who read Jordan's copy in Wisconsin in the course of research for his $\mathrm{PhD}$ dissertation on Mqhayi, is now quite firm in his recollection that USamson is a novel and not merely a retelling of the biblical story (personal communication). With Kuse's confirmation, and despite its disappearance, USamson can be firmly established as the first novel in Xhosa, it can be located within a historical and literary context, and some aspects of its content can be reconstructed from the correspondence columns of contemporary Xhosa newspapers.

In his autobiography, UMqhayi waseNtab'ozuko (Mqhayi of Mount Glory), Mqhayi establishes briefly the social and political context for the publication of the book. Of his early career, at about the turn of the century, he writes:

Ngeli xesha ke sasimi ngezantya, sizama umzi oNtsundu ukuba umanyane, uthethe izwi elinye, ukhale ngesikhalo esinye embusweni. Intoni? Akukho nto yakha yawunqabela umzi oNtsundu njengaloo nto! Yaye impatho ophethwe ngayo ziidolophu ingeyiyo; ibe yanele ukuba ibamanye abantu babe yimbumba, kodwa hayi. Abafundisi nabo baye bephelelwa bubuhlobo nathi, ngenxa yeenkqekeko zaMabandla. URulumente usingene yena ngembumbulu enkulu yobuhlanga, ubuMfengu nobuXhosa. (66-67)

At this time we were busy organizing the people in order to be able to speak in one voice in political affairs, but found that nothing was more difficult for the Black races. Even the hard rule of some Municipalities failed to unite them. European ministers were losing confidence in us, as a result of secessions in the Churches, while the government seemed to be playing off one tribe of Natives against another. (Scott 28)

It was a time of political mobility among blacks, ineffective because of black disunity fostered by the ruling whites; and a time of ecclesiastical secession and the formation of independent African churches (see Odendaal on early black political mobilization, and Pretorius and Jafta on the African initiated churches). Mqhayi's 
autobiography was translated for Dietrich Westermann (and published in German in 1938 as a chapter of Westermann's Afrikaner erzählen ihr Leben a year before Mqhayi's autobiography itself was published) by the prominent educationist W. G. Bennie, the translation quoted above. Crucially, Bennie, the son and grandson of missionary teachers, who was educated at Lovedale and in time became Mqhayi's literary mentor, blunted the reference in Mqhayi's last sentence ("The government pierced us with that great bullet aimed at nationality, Mfengu and Xhosa ethnicity"), probably because Xhosa-Mfengu divisions were still too intense, an enduring sore point in mission circles. The tension between the Mfengu and Xhosa communities dominated social interaction on the Eastern Cape frontier, and constituted a major factor in the reception of USamson. Mqhayi referred to the rift in the community as a "demon" in a later characterization of Chief Nathaniel Cyril Mhala, the first editor of the East London newspaper Izwi labantu, as "u-Sobantu obengenayo konke naledemoni yobu Xosa-Mfengu edungudelisa umzi” 'a Father of the People who was never affected by this Xhosa-Mfengu demon that causes dissension in the community' (Mqhayi, U So-Gqumahashe 20). The ill-feeling between Xhosa and Mfengu derived from white missionary interference in black affairs in the first half of the nineteenth century.

In the eighteenth century, Xhosa-speaking pastoralists moving southwards down the eastern seaboard of southern Africa came into contact-occasionally violent-with Europeans of Dutch descent moving up the same coastal seaboard from the southwest. Clashes between black and white on this eastern frontier persisted throughout the nineteenth century, especially after the British occupied the Cape for the second time in 1806 and some 5,000 British settlers were located along the frontier in 1820: open hostilities broke out in Hintsa's War of 1834-35, the War of the Axe (1846-47), Mlanjeni's War (1850-53), and the final War of Ngcayechibi (1878-79) (see Milton; Mostert; Peires, The House of Phalo). In response to the gradual territorial dispossession of the Xhosa-speaking peoples, and their increasing subjugation to white control, millenarian prophets arose, inciting war (Nxele in 1819, Mlanjeni in 1850) or the catastrophic slaughter of cattle in 1856-57 occasioned by the visions of the teenage girl Nongqaw use. The cattle-killing (see Peires, The Dead Will Arise) was seized upon as an opportunity to integrate frontier blacks into the white farming economy; economic integration was rapidly furthered by migrant black labor essential to the inland mining industry following the discovery of diamonds in 1867 and gold in 1885.

Warfare was not confined to European and Xhosa. Bhaca fought Thembu, Ngqika fought Ndlambe; the northeasternmost of the Xhosa-speaking peoples were disrupted by an influx of refugees fleeing the Zulu king Shaka's territorial expansion early in the nineteenth century. These refugees came to be known collectively as the amaMfengu. On the pretext that they had become the slaves of the Gcaleka, the Methodist missionary John Ayliff gathered and moved them in 1835 after Hintsa's War, resettling them as a buffer between the Gcaleka to the east and the British settlers to the west. The Mfengu thereafter tended to side with their white patrons in the frontier wars, and were deeply resented by the Xhosa. The Mfengu proclaimed loyalty to the British crown and attended mission schools, which were initially viewed with suspicion by the Xhosa chiefs. Tension and rivalry between Xhosa and Mfengu persisted. The Mfengu tended to be assimilationist, the Xhosa nationalist, political strategies reflected in the first 
two independent Xhosa newspapers, Imvo zabantsundu (Black Opinions) and Izwi labantu (The Voice of the People).

The history of Xhosa newspapers in the nineteenth century has been set out elsewhere (see Opland, Xhosa Poets and Poetry ch. 11, and "Nineteenth-Century Xhosa Literature"). Initially, these periodicals served as an extension of the mission enterprise, increasingly through the agency of the Lovedale Institution, founded in 1841. As R. H. W. Shepherd subsequently put it:

In all its efforts for the spread of literature Lovedale recognized that there was a danger lest the missionary agencies, having in their schools taught vast numbers to read, should leave non-Christian and even anti-religious elements to supply the reading matter. [. . .] Great numbers were being taught to read. While in school and when they left it it was imperative that they find within their reach literature suited to their every need, in order that they might have an understanding grasp of Christian life and morals. (Lovedale South Africa 104)

Lovedale's monthly Indaba (News), published between 1862 and 1865, clearly enunciated its evangelical aims:

The Indaba, it is intended, shall contain a Digest of Home and Foreign News, especially as they bear on the interests of the Native Tribes: brief notices of Missionary operations and successes, in this as well as in other lands: and Articles, and, above all, Spiritual Enlightenment of those for whom it is specially designed. In every department, local and party politics will, as far as possible, be avoided. (Indaba August 1862: 13)

Despite the tight editorial control, Indaba fostered the tentative emergence of a literary elite: some native Xhosa-speakers became regular contributors, John Muir Vimbe, for example, William Kobe Ntsikana and Tiyo Soga, translator of the first part of Bunyan's The Pilgrim's Progress, published as Uhambo lomhambi in 1867 (see Hofmeyr ch. 5).

Under its first Principal, William Govan, Lovedale offered all its students a standard Victorian education. As the social and political implications of this educational policy came to be realized, a shift was proposed towards a vocational education for blacks that minimized the study of the classics and mathematics. Govan's reaction was predictable, according to Shepherd:

With his feeling that any lowering of the standard of education was to be deprecated, and his strong conviction that education among a primitive people was advanced by the higher education of the few rather than the elementary education of the many and that Africans were so mixed up with Europeans in South Africa as to render it necessary for them to be placed on an equal footing in matters of education, it could hardly be expected that he would accept the new order of things. (Lovedale South Africa 30)

Govan tendered his resignation and was replaced in 1870 by James Stewart. Stewart soon launched a bilingual newspaper of his own, The Kaffir Express; from 1876 onward, the Xhosa pages were published separately as Isigidimi samaXosa (The Xhosa Messenger) and the English edition became known as The Christian Express. Stewart sought to exercise tight control of the content, excluding politics and 
anything that he saw as an inducement to Xhosa readers to return to a pagan past (including poetry in traditional form). Ultimately, Isigidimi ceased publication in 1888 , the last of the mission newspapers, in the face of competition from a secular Xhosa newspaper, Imvo zabantsundu, established in 1884 in King William's Town by John Tengo Jabavu, the frustrated young former editor of Isigidimi. In the last quarter of the nineteenth-century an educated Xhosa elite had emerged that was determined to co-opt European strategies and technology in the service of its own ends, among them the publication of politically explicit newspapers (see Opland, "Fighting with the Pen" and "Nineteenth-Century Xhosa Literature").

Perhaps the new mood was best reflected in an article by Isaac Williams Wauchope that was published in Isigidimi in June 1882 to Jabavu's editorial acclaim (the full Xhosa text is reprinted in Opland and Mtuze 85-88). The last frontier war had ended yet again with defeat for the Xhosa, the death of some of their chiefs and the imprisonment of others. Wauchope appealed to heroic sentiments especially among school-going youth: "Sitinina ke? Ziti izi pata mandla kuti: Yekani umkonto, pumani kwa Hoho nakwa Mnyube. Yilwani ngo siba. Yizani ke silwe ngo siba" 'What must we do now? The authorities are saying to us: Lay down the spear, come out of the Hoho and Mnyube forests. Fight with a pen. So come on, let's fight with a pen'. Wauchope urged that petitions be drafted and sent to the authorities requesting the release of the Xhosa chiefs. And he ended his appeal with a poem:

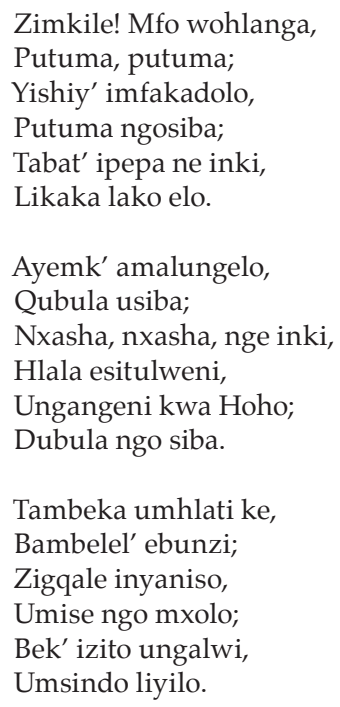

Your cattle are plundered, compatriot!

After them! After them!

Lay down the musket,

Take up the pen.

Seize paper and ink:

That's your shield. 


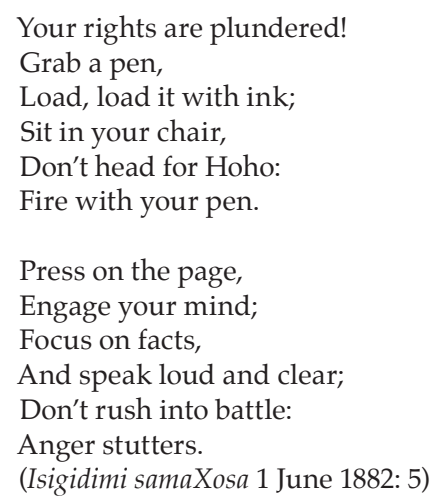

Wauchope was born in 1852 and had been educated at Lovedale (see Opland, "Isaac Williams Wauchope"). He served as one of four Lovedale students who accompanied the missionary party led by Stewart to Malawi, but returned early (see Thompson). As a teacher at Uitenhage, Wauchope served as chairman at the inaugural meeting of Imbumba Yamanyama in 1882, and became the first secretary of this early political organization for black advancement, formed in response to the foundation of the Afrikaner Bond in 1878. Twenty years later, in 1902, the Capebased South African Native Congress was established, giving rise to a network of local vigilance associations.

Independent-minded Xhosa were active not only in politics, but also in church affairs. In 1884, Nehemiah Tile formed the Thembu National Church; in 1900, James Dwane founded his American-inspired Order of Ethiopia. In this spirit, John Tengo Jabavu launched Imvo in 1884 after a three-year spell as editor of Isigidimi (see Ngcongco). Stewart had disapproved of Jabavu's active campaigning for a white electoral candidate; Jabavu chafed under the editorial restrictions imposed on him by Stewart. So Jabavu raised funds from white politicians to found a newspaper of his own in King William's Town, Imvo zabantsundu. Jabavu came in time to support members of the Afrikaner Bond, and believed that blacks should vote for sympathetic white politicians, who would act in their best interests. Jabavu was Mfengu. In reaction, a second group that included Chief Nathaniel Cyril Mhala and Walter Benson Rubusana raised funds from liberal politicians like Cecil John Rhodes to establish a second independent Xhosa newspaper in East London in 1897, Izwi labantu. They were all Xhosa, and the rivalry that ensued between Imvo and Izwi was intense. Rubusana would go on to stand for election himself, and became the first and only black elected to the Cape Provincial Council in 1910. But by then Izwi had failed; it ceased publication in 1909.

On 9 November 1897, in its first issue, Izwi published a poem in its praise attributed to Gompo; subsequent issues continued to feature poems by Imbongi yakwaGompo, (the East London poet), the first pseudonym adopted by the 22-yearold S. E. K. Mqhayi, who had left Lovedale in about 1896 and had accepted a teaching post in East London through the agency of Rubusana. In East London he became active in church and community affairs. As he says in his autobiography, "Ndifakwe ngamandla nasekubeni ndibhale imicimbi yeentlanganiso zomzi, mhla kudityenweyo. Kuthe kanti kukungena kwam oko kwizinto zesizwe, 
neembambano abaNtsundu nabaMhlophe" (UMqhayi waseNtabozuko 65). Bennie translates: "At East London I became secretary to the Congregation and to the Vigilance Association. This gave me my introduction to social questions, and the question of the relations of the races" (Scott 27); Mqhayi's Xhosa is explicit that the races are black and white ("abaNtsundu nabaMhlophe"). Mqhayi tells us that he submitted two unsigned poems for the first issue of Izwi; Rubusana informed Mqhayi that his poems had been accepted and were to appear under the pseudonym Imbongi yakwaGompo, a name Mqhayi embraced, enjoying the attempts in the community to discover the identity of the poet who continued to contribute to the paper under this name. In time Mqhayi became involved in editing Izwi and, subsequently, also Imvo. Rivalry between Imvo and Izwi extended to the literary field: when Mqhayi published in Izwi a poem in exuberant traditional Xhosa style, he was criticized in Imvo by their resident poet, Uhadi waseluhlangeni (Jonas Ntsiko), who wrote in the formalized style of Alexander Pope (see Kuse 19-27).

When Jabavu left to found Imvo, the editorship of Isigidimi was assumed by W. W. Gqoba. For four years, Isigidimi scorned its upstart journalistic neighbor, but Gqoba died suddenly in April 1888, and Isigidimi soon ceased publication, leaving the field to Imvo. For its last four years of publication, Isigidimi under Gqoba exploded with Xhosa literature, much of it contributed by Gqoba himself. Though Isigidimi remained a mission newspaper, Gqoba was able to introduce criticism of the missionary effort in his two long serialized poems, "Ingxoxo enkulu yomGinwa nomKristu" and "Ingxoxo enkulu ngemfundo," a debate between Christian and Non-Christian, and a debate on education. In the latter, for example, one of the speakers who opposes an expression of gratitude to the whites for the education they introduced comments on the differentiated system introduced by Stewart:

Ababantu bayaketa,

Kuyinene inanamhla,

Es'kuleni ndinonyana,

Sel'egqibe nomunyaka.

Isi-Grike akasazi,

Si-Latini, akasazi,

Si-Hebere, akasazi,

Ukukumsha akakwazi.

Wonke umntu onengqondo,

Engotanda kwa nemfundo,

Woziqonda ezindawo

Azimisiley' ubawo.

Kule ngxoxo ndixabene

Nezwi lika-Sweligukwe.

Makavuswe amakwele,

Ozintuli baqatshuzwe.

Ababantu ba Pesheya,

Ngabaze kusibulala,

Basihlute nomuhlaba,

Asinawo namakaya. 
All aren't equal to these people, That's the truth now plain and simple.

I've a son who is a schoolboy,

His first year's already finished.

Greek's a language unfamiliar,

Latin's also unfamiliar,

Hebrew's also unfamiliar,

He's not learnt a foreign language.

Everyone with understanding,

With a love of education,

Will know all about these matters

Put in place for us by Daddy.

This debate has made me quarrel

With the speech pronounced by Guileless.

Bring it all into the open:

Let the dust rise as we argue.

Over oceans came these people

Set in purpose just to kill us,

Take by force our very country:

We no longer have our homesteads.

(Isigidimi samaXosa, 1 January 1885: 5)

The last two decades of the nineteenth century saw the emergence of a Xhosa literary elite, among them writers like Hadi waseluhlangeni, Wauchope, Mqhayi, and Gqoba, who were free to express themselves in newspapers on topics and in styles of their own choice, before the first production of Xhosa literature in books.

The first decade of the twentieth century started with the war between the Boer republics and Britain and progressed to the formation of the Union of South Africa in 1910 through a period of increasing political frustration among South Africa's blacks characterized by A. C. Jordan as "the mounting anguish" (97-102). Rubusana joined other black leaders on a deputation to Britain in a fruitless appeal for the recognition of black rights. The same decade saw the publication of the first works of Xhosa literature in book form. The idea of Xhosa books had been raised in the press, but rejected as inopportune on commercial grounds. In 1888, for example, a few months before his death, with rivalry between the independent Imvo and the mission Isigidimi at its height, Gqoba somewhat dispiritedly replied to an appeal for the collection and publication of articles that had appeared in Isigidimi:

Inteto yako asikuko nokunyanisa kodwa ke kuko into esisixaki kubantu abafundileyo abantsundu, uninzi lwabo alukatali nto yakuhlanga nokuba yiyipina. Alukatalele kufunda na ncwadi yasi Xosa, nayasi Ngesi kwa na pepa la ndaba nokuba lelayipina inteto, into leyo enganiki temba nankutazo nakwabebelinga ukwenza incwadi ezinajalo. Into ekulayo ngamakwele (jealousies) not national ambition, ati lowo akuvelisa into, babe nekwele abangayaziyo bade bayinyelise nokuyinyelisa nje ngempungutye eyazigxekayo idiliya yakubona ingazifikeleli ngemitsi yayo. Ziyakutengwa ngubani na ke ezo ncwadi? 
What you say is quite true, but there is a problem with educated black people: most of them don't care about national issues, whatever their nature. They don't care about reading Xhosa books, or English ones, or even newspapers in any language, which discourages and disheartens those who try to write such things. Instead jealousies are on the increase rather than national ambition, so when something does appear the ignorant grow jealous to the extent that they criticize it like the fox who criticized the grapes he couldn't jump up and reach. So, who will buy these books? (Isigidimi 2 April 1888: 29)

Three years later, Wauchope similarly rejected an appeal for the publication of his series of articles explaining Xhosa proverbs for the younger generation: "While feeling certain of the great value this kind of folklore will be a generation or two hence, I doubt if their publication at the present time would repay the expense of printing" (Imvo 12 Nov. 1891: 3). In 1903, however, the Lovedale Press issued Isaiah Bud M'belle's miscellany Kafir Scholar's Companion containing chapters on Xhosa literature and the Xhosa press, proverbs and versification, as well as notes on vocabulary and grammar, and a bibliography of ethnographic works; in 1904 Lovedale published John Knox Bokwe's Ntsikana: Story of an African Hymn, based on articles that had appeared in The Christian Express in 1878 and 1879; and in 1905 Bokwe's Indoda yamadoda, based on articles that had appeared in Imvo in 1899, on the prophet Nehemiah, including the text of Bokwe's much-loved hymn Vuka Deborah. I have not seen this volume, but a contemporary review by L. L. B. opens with this paragraph:

The above title, which means "A Man Among Men," is that of a new publication by the Rev. J. Knox Bokwe of Ugie Mission. The story, which is that of Nehemiah and the Jewish people of his time from the release to the rebuilding of the walls of Jerusalem, is in the form of a cantata, each chapter being relieved by a suitable song. The music is "of African origin;" as a matter of fact it is composed by the author himself and appeared in his "Lovedale Music." (Izwi 6 Feb. 1906)

Since Bokwe's original four-part series on Nehemiah in Imvo contained neither songs nor music, the newspaper prose version must have been expanded for the book, and its character altered. By 1905, then, Lovedale had started to publish independent works by Xhosa writers in English and in Xhosa. Both M'Belle and Bokwe had cut their literary teeth on contributions to newspapers.

This new mission initiative was accompanied by discussion, much of it ill-informed, in the General Missionary Conferences. To quote from an earlier account:

At the Second General Missionary Conference for South Africa held at Johannesburg in July 1906, Rev. D.D. Stormont presented an appeal for the production of "Christian literary propaganda". Education "amongst the Native peoples" was growing, he noted:

Now ignorance can only be dispelled by knowledge, and in these days the handmaid of knowledge is literature; i.e. the press, the magazine and the book. The spirit of enquiry is abroad, and it cannot be suppressed. It falls to the Christian Church to meet its demands. (Stormont 1906: 73)

Missionaries had recently accepted the crucial role of literature in their task, but had not yet acted on the conviction, Stormont argued, for literature had yet to be produced: 
The Literature for Natives, either in English or in Native languages, might be fully discussed in a chapter as long and as accurate as that famous chapter devoted to Snakes in Ireland: "There are none." Anyhow beyond the titles of two or three small booklets, or translation, the present writer has not been able to find much that could be called literature. (Stormont 1906: 69)

A more informed response to Stormont's appeal at the meeting came from Rev. Edouard Jacottet, who would in the following year issue Thomas Mofolo's Moeti oa Bochabela ["The traveller to the east"], the first Southern Sotho novel, from the Morija Press. Jacottet remarked of Stormont that

The writer saw no Native literature because he did not take pains to see it. A literature was coming into being of considerable proportions in Natal, the Transvaal and the Orange River Colony. Lately there had been a revival of interest for Sesuto literature. (Stormont 1906: 77)

In support of Jacottet's point at the same meeting, "Mr A.W. Baker testified to the desire of the Natives coming under his observation for books and newspapers" (Stormont 1906: 77).

(Opland, Xhosa Poets and Poetry 223-24)

While the missionaries debated and pontificated, two Xhosa authors took matters into their own hands.

In 1906 Rubusana paid for the printing of his pioneering anthology Zemk' inkomo magwalandini (There go the cattle, you cowards) by Butler and Tanner of Frome and London. Rubusana was in Europe in 1905 in connection with the Bible translation, and may have made arrangements then; he engaged an agent in Johannesburg to handle distribution of the volume in South Africa (Mf 4905, School of Oriental and African Studies). The latter part of the volume, which went to a second edition in 1911, consists of an unsurpassed collection of praise poems of nineteenthth-century chiefs, commoners, cattle and horses; the first part is made up of poems and articles culled from early Xhosa newspapers, principally Izwi labantu, and featuring Mqhayi, Gqoba, William Kobe Ntsikana, and other members of the literary elite that had emerged in the previous twenty years. In the following year Rubusana's young protégé S. E. K. Mqhayi paid for the printing of USamson by the Lovedale Press. The fact that both Rubusana and Mqhayi themselves paid for the publication of their books probably stemmed from a desire for independence, free of mission control, in the same spirit in which Imvo and Izwi had been established. Mqhayi issued an advertisement in Izwi labantu on 30 July 1907 that appeared ten times, in each subsequent edition until 1 October 1907:

"U-SAMSON"

Ixabiso yi $6 \mathrm{~d}$ ne $7 \mathrm{~d}$ ngeposi.

Eli ligama LENCWADI ENTSHA (ebomvu-kupuma).

Imbali ka SAMSON etsoliselwe kakulu kmLisela [sic] nom Tinjana okwi Afrika ese Zantsi.

Inokufunyanwa e Lovedale, e Bhayi, e Kapa, e Krugersdorp, kwa Centane, kwi Ofisi ye "Zwi" e Monti, nakwezinye indawo.

Makufundw' incwadi

Kupel' ukuhlala ngabanye.

S.E. RUNE-MQAYI

P.O. Box 1 ,

East London 
"SAMSON"

The price is $6 \mathrm{~d}$, $7 \mathrm{~d}$ including postage.

This is the name of a NEW BOOK (pale red).

The story of SAMSON is aimed especially at South African youth.

It can be bought in Lovedale, Port Elizabeth, Cape Town, Krugersdorp, Kentani, the Office of Izwi in East London and in other places.

Let us read books

And stop gossiping about others.

Mqhayi directed USamson at black youth, with a hint of political activism (it was not noted by the General Missionary Conferences that discussed native literature again in 1909); he was also at pains to establish that the book was printed at Lovedale but had issued from the offices of Izwi, and that he controlled its distribution. On 25 August 1908 a second advertisement appeared in Izwi over Mqhayi's name announcing the availability of his book at the forthcoming SANC Convention:

Konvenshoni e Lovedale

IYAKUMBONA

U SAMSON-

Incwadi enemfundiso

Incwadi enenyaniso

Ilungele abadala

Ilungele nabantwana.

Ixabiso ekaya yi 6d. ne 7d. ngeposi.

Itengiswa zi Arente kwindawo ngendawo. Itengiswa nase LOVEDALE apo yashicilelwa kona. Umtombo wayo ukwi Ofisi ye ZWI. Bhala utunyelwe ubenayo ekaya usingi se ku

S.E. MQAYI, P.O. Box 1

East London.

The Convention in Lovedale

WILL SEE

SAMSON-

A book with education

A book with truth

Suitable for adults

Suitable for youth.

The local price is $6 \mathrm{~d}, 7 \mathrm{~d}$ including postage.

It is available from agents in various places. It is also on sale in Lovedale where it was printed. Its source is the IZWI Office. Write to have a copy sent to you at home to

S.E. MQAYI,

P.O. Box 1

East London. 
Mqhayi tried unsuccessfully to run an advertisement for the book in Imvo. In a letter to the Editor of Izwi published on 19 November 1907, he noted that the Editor of Imvo had failed to print the advertisement Mqhayi sent him. James Ntshona wrote angrily from the Imvo office on 20 November disputing Mqhayi's claim: Mqhayi had sent a request for a quotation for the advertisement, Ntshona maintained, but had not responded to the quote: "Bekungatinina ukuba Incwadana yake kubeko izwi ngayo Emveni kanti noko kunokumangalwa isaziso sayo?" 'How could a word about his booklet appear in Imvo when its quote was not accepted?' (Izwi 26 Nov. 1907: 3). Mqhayi's reaction was published in the 10 December issue of Izwi. He confirmed that no advertisement for his book had been published in Imvo. He had not received the quotation, he claimed, and accused Imvo of dissembling. He repeated Ntshona's rhetorical question, and replied, "Andazi," 'I don't know,' concluding:

Kodwa ke (a) Imvo le ayishicileli zona izinto enezaziso zazo kupela; (b) bendicinga mna ukuti ingaba yilento yokuba Imvo leyo yayitunyelwe ngesisa ikopi ka Samson. Esi saziso ndisatanda ukusibona, nexabiso ndilitunyelwe. Esi izaziso zesimahla bendingazilangazelele nganto zona; kodwa ke ndiyazibulela.

But then (a) Imvo does not print only those items about which it has carried an advertisement; (b) I thought it was because Imvo was sent a free copy of Samson. I am pleased to see this advertisement, and the value it yielded me. I did not much care for the free advertisements but I thank you for them.

The free advertisements Mqhayi thanked Imvo for was the publicity for Samson engendered by the caustic review Imvo published in two parts on 12 and 19 November, penned by I. W. Wauchope.

Bokwe's Indoda yamadoda, dealing with the release of the Israelites from captivity and the rebuilding of the temple, might have offered a model for South African blacks living under white control. Mqhayi's USamson seems to have been by design more politically focused on the youth. Kuse observed that "Mqhayi's first prose piece to be published was social and political commentary. The novella uSamson was a metaphor for the situation of his people and was also an adaptation of the biblical story of Samson and Delilah" (14). Twenty-five years earlier, in 1882 , I. W. Wauchope had directed an appeal to the youth to submit petitions for the release of the Xhosa chiefs. He might have identified with Mqhayi's cause, but in the event he did not. Mqhayi had sent Imvo a review copy of his book; he had approached the King William's Town newspaper for a quote on an advertisement, but no advertisement was ever run by Imvo. It published Wauchope's diatribe and only one other mention of USamson in its pages, a letter on 3 December from G. W. Tyamzashe deploring Wauchope's review and the furore it aroused. Imvo responded to the first Xhosa novel with disdain, in the context of its bitter rivalry with Izwi, and more broadly in the context of the tense relations between the Xhosa and Mfengu communities.

The episodic account of Samson in Judges 13-16 relates an angel's appearance to the barren wife of Manoa, announcing her imminent conception, instructing her not to cut her son's hair, "and he shall begin to deliver Israel from the hand of the Philistines" (13.2). Samson marries a Philistine woman, kills the lion, his wife wheedles the riddle answer from him, and he slaughters thirty Philistines, as a 
result of which Samson is denied access to his wife and sets the fields on fire with burning foxes. His wife and her father are executed, the Philistines raid Samson and arrest him. (In handing him over his friends reproach him: "Do you not know that the Philistines are rulers over us? What then is this you have done to us?") He escapes and slaughters the Philistines with the jawbone of an ass. Samson embarks on a relationship with a prostitute in Gaza, and escapes from ambush, carrying off the city gates. He courts Delilah, she wheedles from him the secret of his strength, he is blinded, and, after his hair has grown again, destroys the house at the festival of thanks to Dagon. Twice, Judges notes that Samson was a judge for twenty years, but no details are given of his career. The principal thrust of Wauchope's criticism was Mqhayi's deviation from this biblical narrative. Wauchope makes his position clear in the opening of his snide review:

Lencwadana ibhekiswa "kumlisela." Uti umbhali wayo "ucapule kulo ncwadi isisimakade," eteta iBible. Ngati kuye i Bible le yincwadi yokufumane umntu "acapule" paya napaya, axomekelele, ongeze nezake ingcinga ukuzalisa indawo acinga yena ukuba kwaposiswa ukuba zingafakwa.

Lembali ka Samson "umlisela" maze uyifunde usazi ukuba kuko into eninzi engekoyo ezi Bhalweni, kuko umpunga ongenguwo walawo maxesha ka Samson, obonakala mhlope ukuba "ucapule" umbhali kula maxesha alamagora alahlekisa abantu ngalamaxesha, waya kudibanisa nebali lika Samson. [. . .] Udwabe nje ngentloko wabeta ecaleni kuzo zonke ezinguqulo ze Bible zikoyo. Yingozi enkulu ke leyo ebonisa ukuba ingapela i Bible le ukuba iyekelwe kulo mbhali.

This booklet is aimed at the youth. Its author states that "he has quoted from this eternal book," meaning the Bible. It seems that to him the Bible is a book anyone can pick up and "quote" piecemeal, with evil intent, supplementing from imagination those places where there are felt to be errors or omissions.

This story of Samson should be read by "the youth" knowing full well that it contains many things that do not appear in the Scriptures, that it has an undertone foreign to Samson's times, as it is quite clear that the author has "quoted" incidents from the times of modern heroes in order to mislead, and has added these to the story of Samson. [. . .] He just wrote off the top of his head and misread all the available Bible translations. This is very dangerous: clearly, if left to this author, the Bible is done for. (Imvo 12 November 1907: 3)

Wauchope criticizes Mqhayi's departure from the biblical text to introduce details of contemporary relevance, adding incidents to the sparse narrative, as well as details of setting and characterization.

Some of Wauchope's comments descend to a petty level, as he himself concedes:

Page 13.-“Batsha nalondlu.-Ewe okunene batshiswa abobantu, kodwa ayiko indawo eti batsha nendlu. Ezindawo angati ongaqondiyo lucuku; kodwa ingapela tu i Bhayibhile ukuba kuvumelekile ukufaka izihlomelo kubafundisi bayo.

Page 13. They burnt in that house. Yes it's true that those people were burnt, but nothing says the house burnt down too. Someone lacking understanding might consider these comments petty, but the Bible would be completely done for if its ministers were allowed to insert additions. 
In the same vein he criticizes Mqhayi for fleshing out the characterization of Manoa ("The bible doesn't say whether Manoa was good or bad"), for adding chapter 2 on customs (and confusing customs and commandments), for fabricating chapter 3 on Samson's childhood, for adding the detail that the Philistine woman Samson courted was mocked by her people and pitied when she agreed to marry him, for mentioning the hills and bushes Samson passed through on his way to his in-laws, for calling Samson "inkokeli yesizwe" 'the national leader' at his wedding, for saying that Samson was unaccompanied at his wedding "Kuba ebe ngena kufumana bantu kowabo ngokunga cingelwa nto kwake" 'Because he could not get people from his own home because he was not well thought of by his own people,' for saying of Samson's future father-in-law "Lom Filistiya wayenayo ingqondo yokumbona lomfana ukuba une zipiwo ezikulu, kanjalo njengendoda enkulu, wayebubona ubupakamo bengqondo yake" "That Philistine had the perception to appreciate that the young man had great gifts and, as a man of rank, he also perceived the depth of his intellect,' for having Samson disappointed on learning his wife had been given to another man, for claiming that Samson enlisted support to catch the foxes, and for saying that those who handed Samson to the Philistines were perturbed and fled home in fear, but he ends by commending Mqhayi for entitling chapter 9 "Ukwapuka kwamandla" (The loss of strength):

Isiqendu IX., Ukwapuka kwamandla. U Mr. Mqayi ngati ufuna ukuvuleka amehlo ngoku. Abantu ababedesha amagora (Hero worshippers), badla ngokuvuleka amehlo bakubona amandla egora esapuka. Baqale babone amaratshi. Sisifundo sokuqala kulencwadi esine siyalo esihle kumlisela, ukuti msa ukuya kuqala abantu ngabom endaweni yabo. Wumbi umntu angati waye yawa zingela amankazana, kodwa umbhali akaboni nto apo-"ugangiwe" u Samson ezihambela.

Chapter 9. The loss of strength. Now it appears Mr Mqayi is prepared to open his eyes. Hero worshippers' eyes normally open when they see a hero's strength lost. Then they start to see pride. This is the first lesson in this book, warning the youth not to rouse people in their own places. A bad person roams about hunting women, but the author doesn't appreciate that: Samson was "pounced upon" as he went on his way.

And Wauchope commends the moral Mqhayi sets on his story on page 22:

He ke, ude wanyanisa umbhali kwizwi ati, "Maninzi ngalemihla amadoda atanda ukuteta ngomlomo esiti ayakubuye enze oku nokuya, kodwa ibe yinkohla ukuyenza lonto, kuba izipiwo zawo azitengise ko Delila abayimihlali, imali, amawonga."-Unyanise kakulu. Maninzi amadoda afuna ukuba zinkokeli, ebatembisa abantu amatamsanqa aza kubenzela wona, kanti ezomali zabantu azama awazo amawonga ngazo. Kwinto ze politics, kwinto zonqulo kwinto zamalungelo emihlaba, kuko injojeli ezipikele ukulahlekisa abantu ezibangele ukuba sibe zezintsali sizizo.

Aha, the author ultimately speaks the truth when he says "There are many men nowadays who love to say over and again they will do this or that but are then unable to because they have sold their gifts to the Delilahs of pleasure, money and status." Too true. Many men want to be leaders, promising people the 
benefits they are going to achieve for them, yet the people's money is used to promote their own status. In politics, prayer, and land rights, there are competing experts who mislead the people, initiating discord.

Wauchope's heaviest sarcasm and most scathing criticism, however, is directed not so much at Mqhayi as at Rubusana, whom Mqhayi credits with offering him advice on his book:

Andazi ukuba u "Rev. Dr. Rubusana" yiyipina eyona nto wati revise yona. Into endiyiqondayo kukuba uqale ngaye kwi "ntshayelelo" wada waya kupela ngaye kwipepa lokugqibela (25). Ekubonakala ukuba lamagora wazisa "umlisela" ngawo mabini—ngu Samson no “Rev. Dr. Rubusana." Sesinye isixaki neso.

I do not know what the "Rev Dr Rubusana" actually did to revise the text. All I understand is that he started with him in the "introduction" and ended with him on the last page (25). It seems there are two heroes he presents to "the youth" in the book-Samson and "Rev. Dr Rubusana." That is a major problem.

Rubusana's knowledge of Hebrew is called into question (as, in passing, is the validity of his American doctorate):

Isiqendu III. 'Umntwana u Samson'-Sonke esi sahluko sesitatu yintsomiyile iti Haba haba. Igama eliti Samson ngesi Ngesi liteta ukuti solar. Andazi ke ukuba ubuhle bungena pina. Kambe uti u Rev. W. Rubusana ka "Zemk' Inkomo," yena wapasa isi Hebere kwabafayo abafundisi, atsho kwinto engaziwa mntu kwabakoyo. Utulana olunjengem alunakugxeka nto ke kwinguqulo yegama lesi Hebere ngu Mr Mqayi encediswa ngu "Dr" lowo wase Monti.

Chapter 3. 'Samson the child'-The whole of this third chapter is a fairytaleit's a lie. The name Samson in English means solar. I don't know where physical beauty comes in. Yet Rev. W. Rubusana of Zemk' inkomo says he passed Hebrew under late missionaries; none of those living knows anything about it. A nonentity like myself can hardly mock the translation of a Hebrew word by Mr Mqayi with the help of this " $\mathrm{Dr}$ " from East London.

When Wauchope criticizes Mqhayi for his embellishments, he will lump him together with Rubusana, as in "Uti 'abangcatshi bake lalise libakohlile basaba baya ngendawo zabo beguba.' Zezombhali ezo indaba, kunye no Mr. Reviser. Asizazi tina zidenge" ‘He says "his betrayers were confused and fled home trembling in fear." This is news from the author and Mr Reviser. Fools like us know nothing about that.' Samson misleads its readers by inviting them to expect biblical narrative, not fiction; so too, he argues, Rubusana's Zemk' inkomo misleads in containing the writing of many and not just Rubusana, who is presented as the author. And he concludes his review with a dismissive comparison of Samson and Rubusana, and with a final dig at Mqhayi, depicted as Rubusana's praise poet:

Elibali liqale ngombulelo ku Dr. Rubusana, lipela ngomqukumbelo wamazwi elogora lanamhla. Kula magora mabini elinye alipumelelanga kuba aliwakululanga ama Sirayeli. Elamva alikapumeleli ntweni, asika ncami ke. Kodwa ngati ezimbongi zalo ziyakulenza ukuba ligaxaze. Kwanga kungebinjalo. 
This story started with thanks to Dr Rubusana, and ends with concluding words from that modern hero. Of these two heroes, one did not succeed because he failed to free the Israelites. The latter has not yet succeeded in anything, yet we live in hope. But it looks like his praise poets will get him to work quickly. Let it not be so.

We can make allowances for Wauchope's bias and draw some conclusions about USamson. The red-covered book, twenty-five pages long, was printed by the Lovedale Press but probably paid for and certainly distributed by the author himself. The only biblical episode Wauchope does not refer to in his review is Samson's dalliance with the Philistine prostitute, but it may well have been included: Mqhayi seems to have followed the narrative closely. To it he added details of setting and characterisation, and at least two sections, a chapter on Hebrew customs and another on Samson's childhood. In a later book, Idini (1928), on Xhosa customs of sacrifice, Mqhayi was at pains to establish parallels between Hebrew and Xhosa custom, and this may have been his motive for the second chapter of USamson. Certainly missionary responses to Xhosa custom had for some time been a topic of impassioned debate in the press, a major contributor to the controversy being I. W. Wauchope. The principal innovation in Mqhayi's text was in fleshing out the character of Samson (in the chapter on his childhood and elsewhere), in appeals to the Xhosa youth and in references to Dr. Rubusana. Mqhayi made Samson intelligent, a solitary figure, handsome and attractive to women (who ambushed him), selfconfident and heedless of advice, ready to retaliate, a national leader despised by his own people and somewhat alienated from them. Much of this derives logically from biblical narrative. His alienation, for example, would explain his courtship of Philistine women, but the latter trait seems to have been given especial emphasis. Of the chapter on Samson's childhood, Wauchope writes:

Lo Samson ngoku lihilihili, into ehamba ezindle, igeza, into engahlali 'ndlwini, into "edlala into zayo ipele ngelayo." [. . .] Lo Samson uhamba ezintabeni ati ukuba sekaya lomini kukale abafazi besiti "Hlala mntanam ndiyakuyibeta lanto inwele zimayakayaka."

This Samson is now a vagabond who roams the veld raving, who does not want to stay at home, someone "who does as he pleases." [. . .] This Samson walks the mountains and when he returns home for a day the women cry out saying "Sit, my child. I'm going to whip that thing with unruly hair."

Mqhayi created a hero withdrawn from his people, isolated, and lacking support and sympathy at home.

Mqhayi may well have appealed to the youth to admire and throw their weight behind an intelligent national leader who was not drawing sufficient support, who would work for the liberation of his people from foreign control through aggressive confrontation. He seems to have been critical of those who failed to support such a leader in the past, and addressed the youth as a new constituency. Wauchope chose to agree with Mqhayi on this point, that such a leader lost strength and lacked support, but criticized the leader for divisive, selfseeking strategies that elicited apathy. Both Mqhayi and Wauchope assailed a community that lacked cohesion, that had split over Xhosa and Mfengu strategies 
of engagement. Writing for the King William's Town-based Imvo, Wauchope seems to have identified Mqhayi's Samson with a faction from East London, where Izwi was published. Indeed, Wauchope seems to read Mqhayi's story of Samson and the characterization of his hero as a thinly veiled figure of Mqhayi's mentor W. B. Rubusana. This suggestion would explain Wauchope's vituperative response to Mqhayi's novel, as dismissive of the author as of Rubusana.

Mqhayi himself responded to Wauchope's criticism calmly, with wit and grace, turning it to his advantage. On 19 November, Izwi carried this letter:

\section{U Samson}

U Rev Isaac W. Wauchope umfundisi wakowetu kwam, ose Bofolo, unencwadi azibhala kwipepa le Mvo ngayo lencwadana. Incwadi zalemfundisi zibhalwe ngendlela endingati ukuyibiza yeyona ndlela isisitete kuti ma Xosa kuba inkwenkwe xa ibongwayo ibizwa ngarabaxa, ukuze kuqondwe ukuba inesimbo. Kodwa xa yenileyo ibizelwa ecaleni iboniswe iziposo zayo, iyalwe okanye yohlwaywe.

U Mhleli welopepa ndati ndakumtumela isaziso ngo "Samson" akaze wasifaka; kodwa ndiyabulela kuba kwinqaku awake walenza u Mhleli lowo, baba baninzi abayifunayo incwadana le. Anditandabuzi ukuba ezi incwadi (articles) zibalwa ngu mfundisi ka bawo, ziyakwenza isaziso esizeleyo.

U Samson ufunyanwa: E Bhayi, ko Messrs A. Ross, S. G. Heshu, J. G. Gaba no F. Bom; Komani, Mr. RB Mlilwana; e-Rini, ku Mr Wm Maqanda; e-Kapa, Messrs L. Soha, DD Tywakadi; Centane, Mr. Russel Koti; Kimberley, Miss IG Bobo; Cullinan, Mr Wm Ludada; Mt Coke Mr J Tunyiswa. Ndiyayishiya I Monti kwanabatengisi abatate idazini nganye.

Ukuba u Rev. I. Wauchope angatanda ukunditengisela e Bhofolo paya bangambulela kakulu abantu bakona kunye nam.

U Samson azikabi ntatu inyanga eshicilelwe, kodwa ikopi ezitengiweyo zingapezu kwama 500; ndandishicilele iwaka e Lovedale. Ngalendlela ndiyaqonda ukuba awakowetu azimisele ukuyixasa lencwadana nango ncedo lwabafundisi abamana ukundilola besenjenje, nabanye ngezinye indlela endiya kubuye ndizibeke nezo incwadi (letters) esishicilelweni.

Oyifunayo atumele izitampo ze 7d kumniniyo.

S.E. MQAYI,

P.O. Box 1 ,

East London. (Izwi 19 November 1907: 3)

\section{Samson}

Rev. Isaac W. Wauchope, one of our ministers in Fort Beaufort, has written letters to Imvo about this little book. The letters of this minister are written in a style which I regard as traditional among us Xhosa people, because when a boy is praised he is addressed roughly so that he can be recognized to have style. But when he has done wrong he is taken aside and shown his failings, encouraged or punished.

When I sent the Editor of that paper an advertisement about Samson he failed to publish it; but I am grateful because the remarks the Editor published led many people to want the booklet. I have no doubt that these articles written by my brother the minister will serve as a complete advertisement. 
Samson can be obtained: in Port Elizabeth, from Messrs A. Ross, S. G. Heshu, J. G. Gaba and F. Bom; in Queenstown, from Mr. R.B. Mlilwana; in Grahamstown, from Mr. Wm. Maqanda; in Cape Town, from Messrs L. Soha, D. D. Tywakadi; in Centane, from Mr. Russell Koti; in Kimberley, from Miss I. G. Bobo; in Cullinan, from Mr. Wm. Ludada; in Mt. Coke, from Mr. J. Thunyiswa. I omit East London, from sellers who have taken a dozen each.

If Rev. I. Wauchope would like to sell the book for me over there in Fort Beaufort the local people and myself would be most grateful to him.

It is hardly three months since the publication of Samson, but over 500 copies have been sold; I had one thousand printed in Lovedale. In this way I believe our community is prepared to support this little book, with the help of ministers who keep whetting me, and others whose suggestions I will return to in future, and also the publication of letters.

Anyone who wants a copy should send $7 \mathrm{~d}$ in stamps to the author.

S. E. Mqhayi

Wauchope's review in Imvo elicited a lively correspondence in Izwi critical of Wauchope and Jabavu, encouraging and praising Mqhayi's effort. Many denounced Wauchope's transparent attack on Rubusana, and bemoaned the factionalism of Christian sects. Some accused Wauchope of jealousy and urged him to write a book of his own. Umona asinto inaciko, intoned Bryce Balfour, jealousy lacks eloquence (Izwi 10 Dec. 1907: 4). Mqhayi had clearly started something: a number of correspondents looked forward to further books. D. D. Vena suggested that Wauchope was jealous of Rubusana, slyly advising Mqhayi to consult Wauchope when he produced a second book. M Sam Buqa wrote from Cape Town:

Ndiyasela mhleli lombulelo egameni lomtinjana nomlisela. Emzini ontsundu owenze incwadi ezizezi. Indoda Yamadoda ngumfundisi u Bokwe, Zemk' inkomo Magwalandini Dr. Rubusana u Samson Mr. S. E. Rune-Mqayi noko ngati kute cwaka nje umtinjana uyaqwala sela, uyayiva. Lemikwazo yomitatu. Lemikwazo i Balulekile, ncam zeningapiki, nento eziminwe mide. Kukuhlala komntu oswele umsebenzi ukuba nomnwe omde. Wokuhlaba izinto ezisentywenza ngabantu. Engenanto yena enzayona.

U I.W.W. Besiya kumpendula sitete naye xa ebevele necebo lobudoda. Mhlaumbi nencwadi, kungenjalo kwelelani ngasemva, nipulapule imikwazo yamadoda akonza amawawo. Pulapula wena usempelazwe.

A word of thanks, Editor, in the name of the teenage girls and boys, to the black nation that has produced the following books: Indoda Yamadoda by Rev. Bokwe, Zemk' inkomo Magwalandini by Dr Rubusana, USamson by Mr. S. E. Rune-Mqayi. Though everything appears quiet the youth are watching keenly and listening. These three voices of theirs are conspicuous. Pay no attention to long-fingered things. Long fingers grow on idle hands. They criticize the work of others while they do nothing themselves.

We would have responded to I. W. W. and engaged with him had he come up with a manly solution or perhaps even a book. Otherwise stand back and listen to the voices of men who serve their people. Listen, you in the wilderness. (Izwi 10 Dec. 1907: 4)

In the same issue, Kleinboy Dyani wrote from Ndabeni in Cape Town: "Lixesha ngoku mfundisi lokuba amadoda antloko zintle enze incwadi zokunceda isizwe" 
'Now is the time, minister, for intelligent men to write beautiful books to aid the nation.' And he neatly captured the significance of Mqhayi's achievement:

Malunga nencwadi ka Mr Mqayi yena akasenancwadi ngoku loncwadi seyiyincwadi yomzi wonke ontsundu wase South Africa, kuba yapuma ezandleni zake seyiyeyam ngoku nose Matshona nose Zambesi nokwa Zulu, nokwa Mzilikazi yeyake.

As for Mr. Mqhayi's book I can say he no longer has a book. This book now belongs to all the black people of South Africa, for it has left his hands. It is now mine, and among the Shona of Zambesi, it belongs to one who is in the land of Zulu and Mzilikazi.

Wauchope would indeed produce a book of his own in the following year, the subversive The Natives and Their Missionaries published by the Lovedale Press in 1908 (see Opland, "Fighting with the Pen"). In the same year Wauchope was found guilty of forging a parishioner's will and committed to Tokai prison. He emerged after serving a three-year sentence (during which his wife died), published a series of poems he had written in prison, joined the South African Native Voluntary Contingent and was drowned on the troopship Mendi in the English Channel on the night of 21 February 1917, heroically urging his doomed colleagues to stay calm and die like proud Africans. Mqhayi went on to become the greatest and most prolific figure in Xhosa literature, publishing prize-winning fiction, poetry, an autobiography and translations, contributing regularly to various newspapers while continuing to serve as the most distinguished praise poet the Xhosa tradition has known. He was the author of such classics as Ityala lamawele (1914), U-bomi bom-fundisi u John Knox Bokwe (1925), Imihobe nemibongo (the first volume of poetry by a single author, 1927), UDon Jadu (1929), Umhlekazi uHintsa (1937), UMqhayi waseNtab'ozuko (1939), and Inzuzo (1942). Pre-eminent as he is in the history of Xhosa literature, Lovedale still rejected some of his works for publication: on 18 April 1940, R. H. W. Shepherd returned Mqhayi's biography of Rubusana, explaining that it showed bias in recording relations between Rubusana and Jabavu: "As a missionary press, we cannot allow ourselves to become involved in political controversy making for division among the Bantu people" (Cory Library for Historical Research MS 16,321c). Clearly missionary circles remained sensitive to the Xhosa-Mfengu tension.

As a young boy Mqhayi fled from fights, earning the poetic praise "Ntak' enamandla sisinagogo / Kuba sibalek' amathumb' elenga-lenga" 'the powerful bird's the barbet: it flees with its guts spilling out' (UMqhayi waseNtabozuko 79). His generosity of spirit and reluctance to engage in fights continued to characterize his response to Wauchope. In 1911, he wrote an obituary for Naniwe, Wauchope's wife, and in 1935 published "Umfi u Mfundisi Isaac William Wauchope" (The late Rev. Isaac William Wauchope), a fulsome tribute to Wauchope, who, in his death ten years after he published his intemperate criticism of USamson, had become a national hero as worthy of emulation as Samson or Rubusana. Mqhayi's is the earliest source of evidence linking Wauchope to his legendary actions on the sinking troopship (the earliest source located by the most recent commentator dates from 1941; see Clothier 58): 
Uthi owayelapho kuxa ngoku igorha lakwa Ngqika elizalwa ngamanye, lithe qabavu phaya logama itshonayo inqanawa! Line thuba njengomthandazeli lokuba lingene ephenyaneni lisinde, kodwa aliyi! Liyawuthethela loomkosi ungenabani nokuwuthethela ukuba uzele, ufe ngokwamagora abephume umkosi! Kuthiwa uthi:-

Zolani kaloku ma Laundini!

Kwamkeleni ngoguzol' ukufa kwenu!

Nantso lonto benize kuyo!

Nawashiyela lont' amakhay' enu,

Taruni makhaliph' akowethu!

Taruni mathol' amagora,

Namha nikwimini yokuphela,

Lungisani izibuko lokugqibela! (The Bantu World 19 Jan. 1935: 6)

Those who were there say the hero from Ngqika's land descended from heroes was standing aside now as the ship was sinking! As a chaplain he was free to board a boat and save himself, but he didn't! He kept on appealing to the leaderless soldiers urging them to stay calm, and die like heroes on their way to war. We hear that he said:

Now then stay calm my countrymen!

Calmly face your death!

This is what you came to do!

This is why you left your homes!

Peace, our own brave warriors!

Peace, you sons of heroes,

This is your final day today,

Prepare for the ultimate ford! ...

Ngakho ukutshona kwayo lenqanawa ama Xhosa alahlekelwe ngoonyana bawo abathembhekileyo; kodwa lathi lakuvakala igama lalo mfundisi, phakathi kwabangasekoyo, wenzakala ngakumbhi umzi, kwaqondakala ukuba u Xhosa ufumene isiva esibi, nelahleko enkulu, nokutshonelwa yinkwenkwezi yakhe eqaqambe kunene.

Awu!!!

Savakal' isililo sika Nojoli,

Isikhalo nesijwili somka Rarabe,

Intokazi kaNomagwayi wase Mbo.

Ililel' uluhle olumke namangaba-ngaba,

Ite'alufanga lusing' emandleni!

Tarhuni mabandla ka Palo,

Mabandla ka Ngconde ka Butsolo-bentonga.

Kungabanje k' umz' unyembelekile,

Yatshon' inkwenkwezi ka Cizama

Waphuk' umqol' umzi ka Xhosa!

Eyona nkwenkwezi yokugasa kwethu,

Thole lesilo lafa lithetha,

Lafa libongisela lafa liyolela!

Wath' umntu nants' inkongolo yokufa,

Iza ngebhaqo kwelase mzini.

Kwingxingw' ephakathi kwenkunz' ezimbini. (The Bantu World 26 Jan. 1935: 4) 
With the sinking of this ship, the Xhosa people lost their reliable sons; but when the name of this chaplain was mentioned among the dead, the nation was dealt a grievous blow. Clearly Xhosa himself suffered a severe wound, a massive loss, at the setting of this brilliant star of his.

Ow!!!

Nojoli's cry was heard,

the keening cry of Rharhabe's wife,

daughter of Nomagwayi of eMbo,

bewailing the beauty swept out to sea,

saying death hadn't claimed them, they were growing in strength!

Peace, Phalo's people,

Ngconde's, Butsolobentonga's.

At times like these a nation despairs.

Chizama's star has set,

the Xhosa nation's back is broken!

The best of stars we took such pride in,

the animal cub died while talking,

died giving heart, securing his testament!

Someone said what an unseemly death,

suddenly coming in alien territory,

in a strait between two bulls....

Hamba nzwan' enkulu yakwa Cizama!

Nguwen' uyakuty' isithubi no Thixo.

Thina ma Xhos' asimz' ufayo

Sigwetywa ngovuko lwabafileyo

Ukufa kuthi yinzuzo nengenelo.

Luba kulap' amandla azuzwa khona;

Kuba kulap' amend' azuzwa khona;

Hamba Cizama sikuvumele,

Wasa kusilibal' aph' e Nyangwaneni.

Ncincilili!

Ncincilili!!

Ncincilili!!! (The Bantu World 26 Jan. 1935: 4)

Go, prince of Chizama's place!

You'll be eating porridge with God.

We Xhosa people never die,

we're judged when the dead arise,

death to us is profit and gain,

for there we get our strength,

for there we get our speed.

Go, Chizama, we grant you leave.

Never forget us there in the highest.

I'm finished!

I'm finished!!

I'm finished!!!

The bible is susceptible to literary appropriation. It can be the source of humor and parody, as in an American "street corner song": 
Samson was a strong man of the John L. Sullivan school,

He slew ten thousand Philistines with the jawbone of a mule.

But Delilah captured him and filled him full of gin,

Slashed off his hair and the coppers run him in.

Samson was a husky guy as everyone should know,

He used to lift five hundred pounds as strong man in his show.

One week the bill was rotten, all the actors had a souse,

But the strong-man act of Samson's, it just brought down the house.

(Cohen 299)

Mqhayi's intention in USamson was more serious, closer to Zora Neale Hurston's in her novel Moses: Man of the Mountain (1939), in which she drew parallels with the situation of African Americans by giving black folk dialogue to her Hebrew characters. Like Hurston's Harlem Renaissance novel and the street song, Mqhayi seems to have incorporated explicit links between the biblical narrative and his own times; it is clear from the newspaper correspondence that contemporary readers readily drew political parallels, identifying Samson with W. B. Rubusana, recognizing Samson as a hero who actively resisted his people's oppression.

In 1909, Henry Masila Ndawo's allegorical novel Uhambo lukaGqoboka (Convert's Journey), indebted to Bunyan's The Pilgrim's Progress, was published by the Lovedale Institution. According to Gérard, "It tells the story of an African's indomitable struggle to give up heathenism and embrace the Christian faith" (63). Letitia Kakaza wrote two pious novels that were published in 1913, Intyatyambo yomzi (The Flower of the Home), "dealing with the fortitude of a girl who overcame temptations until the day of her death" (Gérard 65), and 1914, UTandiwe wakwa Gcaleka (Tandiwe of the Gcaleka). Mqhayi's USamson, unlike these pious works, used biblical material to political ends: it was secular in intent. His next novel, Ityala lamawele (The Court Case of the Twins), published in the same year as Kakaza's second work, was set in earlier times, and was designed to demonstrate that the Xhosa had developed their own legal system, independent of white jurisprudence. Mqhayi achieved widespread celebrity as a Xhosa author. In 1917, he was accorded the honorific soubriquet "Imbongi yesizwe jikelele" " the poet of the whole country,' for rising above parochial considerations and addressing himself to the black people of South Africa as a whole. Unfailingly political as imbongi or writer, Mqhayi sought the well-being of all of South Africa's black people. In Wandile Kuse's view,

His first novel, an adaptation of the biblical story of 'Samson and Delilah', entitled USamson (1907), offered a critique of South African society in the years following the Anglo-Boer War. He conceived of the 'natives' as the impotent 'sleeping giant' who, in the words of Shakespeare's Mercutio, willed and wished 'a plague on both your houses'. The image was sustained by the Titan's act which brought to ruin the edifice constructed by the collusion of liberal white men and reactionary racists at the expense of the indigenous peoples of South Africa. Mqhayi was always aware that the intrusion of Europeans into the patterns of behaviour and politics of Africans was not always gentle and altruistic. (50)

In his autobiography, Mqhayi writes of Izwi labantu: 
Iphepha livalwe sendikhe ndabhala, ndashicilelwa incwadana egama ndathi, nguSamson; yashicilelwa eLovedale. Badywidana abantu ngayo yaphela. Baye beyibuka beyithakazelela kakhulu; kuba neencwadi zesiXhosa oko zazingekabi ngakanani. Isamana ukubuzwa nangoku loo ncwadana kum. Ndithembise ukuba iza kushicilelwa, iimeko zakulunga. (68)

Before the closing down of the paper, I had written a pamphlet entitled Samson and had it printed at Lovedale. People soon bought out the edition, and spoke in high terms about it. Further there was not much of Xhosa literature in those days. Enquiries for a second edition are still made, and I hope to republish it as soon as circumstances permit. (Scott 29)

Circumstances never did permit, but to his unsurpassed contributions to Xhosa literature may now be added S. E. K. Mqhayi's singular achievement as the author of the first Xhosa novel.

\section{NOTE}

I am deeply indebted to Peter Mtuze and Abner Nyamende for assistance with the translations from Xhosa.

\section{WORKS CITED}

Clothier, Norman. Black Valour: The South African Native Labour Contingent, 19161918 and the Sinking of the "Mendi". Pietermaritzburg: U of Natal P, 1987.

Cohen, J. M., ed. Comic and Curious Verse. Harmondsworth: Penguin, 1952.

Gérard, Albert S. Four African Literatures: Xhosa, Sotho, Zulu, Amharic. Berkeley: U of California P, 1971.

Hofmeyr, Isabel. The Portable Bunyan: A Transnational History of "The Pilgrim's Progress." Johannesburg: Wits UP, 2004.

Jordan, A. C. Towards an African Literature: The Emergence of Literary Form in Xhosa. Berkeley: U of California P, 1973.

Kuse, Wandile F. “The Form and Themes of Mqhayi's Poetry and Prose.” Diss. Madison: U of Wisconsin, 1978.

Milton, John. The Edges of War: A History of Frontier Wars (1702-1878). Cape Town: Juta, 1983.

Mostert, Noël. Frontiers: The Epic of South Africa's Creation and the Tragedy of the Xhosa People. London: Cape, 1992.

Mqayi, S. E. Rune. U So-Gqumahashe (N.C. Umhalla). Lovedale: Lovedale Mission P, 1921.

Mqhayi, S. E. Krune. UMqhayi waseNtabozuko. 1939. Lovedale: The Lovedale P, 1964. Idini. Johannesburg: Caluza City Sbbn, nd.

Ngcongco, L. D. “John Tengo Jabavu 1859-1921.” Black Leaders in Southern African History. Ed Christopher Saunders. London: Heinemann, 1979. 142-55.

Odendaal, André. Vukani Bantu! The Beginnings of Black Protest Politics in South Africa to 1912. Cape Town: David Philip, 1984.

Opland, Jeff. Xhosa Poets and Poetry. Cape Town: David Philip, 1998. . "Isaac Williams Wauchope." The New Dictionary of South African Biography. Ed. Nelly E. Sonderling. Pretoria: Vista UP, 1999. 237-39. 
"Fighting with the Pen: The Appropriation of the Press by Early Xhosa Writers." Orality, Literacy, and Colonialism in Southern Africa. Ed. Jonathan A. Draper. Atlanta: Society of Biblical Literature; and Pietermaritzburg: Cluster Publications, 2003. 9-40.

. "Nineteenth-Century Xhosa Literature." Kronos: Journal of Cape History 30 (2004): 22-46.

and Mtuze, P. T.. eds. Izwi labantu. Cape Town: Oxford UP, 1994.

Peires, J. B. The House of Phalo: A History of the Xhosa People in the Days of Their Independence. Johannesburg: Ravan, 1981.

. The Dead Will Arise: Nongqawuse and the Great Xhosa Cattle-Killing Movement of 1856-7. Johannesburg: Ravan, 1989.

Pretorius, Hennie, and Jafta, Lizo. "'A Branch Springs Out': African Initiated Churches." Christianity in South Africa: A Political, Social and Cultural History. Ed. Richard Elphick and Rodney Davenport. Cape Town: David Philip, 1997. 211-26.

Scheub, Harold. "Xhosa Oral and Literary Traditions." Literatures in African Languages: Theoretical Issues and Sample Surveys. Ed. B. W. Andrzejewski, S. Pilaszewicz, and W. Tyloch. Cambridge: Cambridge UP, 1985. 529-609.

Scott, Patricia E., ed. Mqhayi in Translation. Communication No. 6. Grahamstown: Department of African Languages, Rhodes U, 1976.

Shepherd, R. H. W. Bantu Literature and Life. Lovedale: Lovedale P, 1955. . Lovedale South Africa 1824-1955. Lovedale: Lovedale P, 1971.

Stormont, D. D. "Literature for Native Christians." Report of the Proceedings of the General Missionary Conference for South Africa held at Johannesburg July 5-11, 1906: 68-76.

Thompson, T. Jack. Touching the Heart: Xhosa Missionaries to Malawi, 1876-1888. Pretoria: U of South Africa, 2000. 
Copyright of Research in African Literatures is the property of Indiana University Press and its content may not be copied or emailed to multiple sites or posted to a listserv without the copyright holder's express written permission. However, users may print, download, or email articles for individual use. 